\title{
Governance en Onafhankelijkheid in het Accountantsberoep
}

Citation for published version (APA):

Hassink, H. F. D. (2004). Governance en Onafhankelijkheid in het Accountantsberoep. Universiteit Maastricht. https://doi.org/10.26481/spe.20041015hh

Document status and date:

Published: 15/10/2004

DOI:

10.26481/spe.20041015hh

Document Version:

Publisher's PDF, also known as Version of record

\section{Please check the document version of this publication:}

- A submitted manuscript is the version of the article upon submission and before peer-review. There can be important differences between the submitted version and the official published version of record.

People interested in the research are advised to contact the author for the final version of the publication, or visit the DOI to the publisher's website.

- The final author version and the galley proof are versions of the publication after peer review.

- The final published version features the final layout of the paper including the volume, issue and page numbers.

Link to publication

\footnotetext{
General rights rights.

- You may freely distribute the URL identifying the publication in the public portal. please follow below link for the End User Agreement:

www.umlib.nl/taverne-license

Take down policy

If you believe that this document breaches copyright please contact us at:

repository@maastrichtuniversity.nl

providing details and we will investigate your claim.
}

Copyright and moral rights for the publications made accessible in the public portal are retained by the authors and/or other copyright owners and it is a condition of accessing publications that users recognise and abide by the legal requirements associated with these

- Users may download and print one copy of any publication from the public portal for the purpose of private study or research.

- You may not further distribute the material or use it for any profit-making activity or commercial gain

If the publication is distributed under the terms of Article $25 \mathrm{fa}$ of the Dutch Copyright Act, indicated by the "Taverne" license above, 
Governance en Onafhankelijkheid in het Accountantsberoep 


\section{Collofion}

6horold r. Ho Hosink 2004

Hassisont werp en realisatie. Unigrophic, Unwersiteit Moastricht.

$1564909687 \cdot 227 \%$

Nur 786

Ahe rechten wowbehouden. Niets uit deze uitgane mag worden verweelwoudigd, opgeslagen in

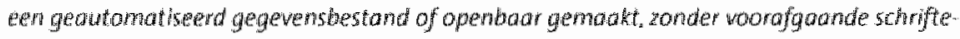
like toertomming wan de auteur of uitgewer. 


\section{Governance en Onafhankelijkheid in het Accountantsberoep}

\section{Rede}

in verkorte vorm uitgesproken bij de aanvaarding van het ambt van hoogleraar in de Bedriffseconomie, in het bijzonder Auditing aan de Faculteit der Economische Wetenschappen en Bedrijfskunde van de Universiteit Maastricht

op wrijdag 15 oktober 2004

door

Prof.dr. H.F.D. Hassink RA 

Mijnheer de Rector Magnificus,

Dames en Heren.

\section{Algemene inleiding}

\subsection{Inleiding}

Hebt $u$ ook zo'n hekel aan die praatjes van die weermannen op de televisie die de eerste tien minuten uitvoerig schetsen hoe het weer in elke uithoek van Europa is geweest, die vervolgens, na de reclame aangeven hoe het weer op elk van deze plaatsen gaat worden om te eindigen bij de vraag waar het om draait, namelijk of het morgen droog blijft en of je dus met de fiets naar je werk kunt? Helaas heeft mijn bijdrage enige gelijkemis met de praatjes van de weermannen. ik wil eerst met $u$ achterom kijken naar een aantal ontwikkelingen dat de accountantsprofessie heeft doorgemaakt om vervolgens vooruit te blikken om met aanbevelingen voor betrokkenen te komen. Daar houdt de gelijken is met de praatjes van de weermannen op. U kunt mij niet wegzappen maar daar staat tegenover dat mijn bijdrage niet wordt onderbroken door reclame.

Zoals bekend heeft Nederland na de Tweede Wereldoorlog een stormachtige economische ontwikkeling doorgemaakt waaraan accountants een belangrijke bijdrage hebben geleverd.1 $\mathrm{Na}$ de sobere jaren wiftig begon in de jaren zestig het welvaartsniveau te stijgen. Tegelijkertijd werden de calvinistische veren afgeschud en in de jaren tachtig werd veel geld verdiemen niet langer als onethisch gezien. in de jaren negentig ontdekten particulieren aandelen. Op verjaardagsfeestjes werd niet meer over voetbal maar over aandelen gesproken. Bestuurders van beursgenoteerde vennootschappen werden de nieuwe volkshelden met megasalarissen en superbonussen, toegekend door een kleine zakelike elite. Topbestuurders speelden een spel zonder nieten; een spel van alles of veet. Door agressieve bonusstructuren ontstond een cultuur van risj. co's nemen en kansen grijpen. Megabonussen legden grote druk op top. bestuurders om de gestelde doelen te realiseren. Op hun beurt zetten zil de organisatie onder druk om te presteren. Ook de financiele kolom ontkwam daar niet aan. Toen de economische groei terugviel en de motor

"Voor historische overzichten met betrekking tot de rol van de accountunt in Nederland zie De Vries (1985) en De Hen et al (1995). 
begon te haperen werd door sommige ondermemingen de druk op de accountant opgevoerd om te helpen de werwachtingen in te lossen. Wat decenmialang alleen maar een hialat in het Nederlandse bedrijfsleven was, werd plotseling een probleem voor de accountancy. Er bleken niet altijd voldoende checks and bolances in de accountancy-branche te zijn on de druk wan het bedrifsleven te mitigeren. Ondertussen verloren sommige accountants de positie van het maatschappelijk verkeer uit het oog. Door het ontbreken van extern toezicht op de accountancybranche werd deze ontwikkeling te laat gesignaleerd en onvoldoende gemitigeerd. De bedrijfstak, die in krap 100 jaar van niets tot een miljardenindustrie was geworden werd, en is nog steeds, onderwerp van publiek debat. Als $u$ het accountantsberoep een klein beetje volgt zal u dit niet zijn ontgaan.

Wat $u$ ook niet zal zijn ontgaan is het feit dat in de Verenigde Staten het energicbedrijf Enron is omgevallen. In het kielzog daarvan was Arthur Andersen, een van de vijf grote accountantskantoren wereldwijd hetzelfde lot beschoren. Ook Nederiand is niet verschoond gebleven van gevallen waarbij vraagtekens werden gezet bij het functioneren van accountants, ik refereer hierbij aan Ahold, de Bouwfraude en aan Parmalat. Overigens is dit niet nieuw. Ik herinner me zaken uit de jaren negenting als Daf, Vie d'Or. Heino Krause, Chipshol waarbil de accountant ook niet altijd buiten schot bleef. Ongetwijfeld herinneren de wat oudere accountants zich zaken uit de jaren daarwoor.

Er is echter een belangrijk verschil tussen de zaken die in de jaren negentig speelden en de zaken die de afgelopen jaren het nieuws haalden, In het wat verdere verleden blewen maatschappelijk verkeer en politiek bij problemen op afstand. In die jaren was er nog veel vertrouwen in het zelfregulerend vermogen wan het accountantsberoep. De afgelopen jaren hebben incidenten echter krachten in de samenleving en in de politiek losgemaakt die vraagtekens zetten bij de checks and balances in de accountancy. Uiteindelijk heeft dit geleid tot de Sarbanes-Oxley Act in de Verenigde Staten, Aanbevelingen voor Onafhankelijkheidsregels woor Accountants in de EU en de Wet Toezicht Accountantsorganisathies in Nederland.

Mij lijken genoemde nieuwe wetten, regels en toezicht niet meer en riet minder dan een volgende stap in de verdere institutionalisering van het accountantsberoep. Een ontwikkeling die is begonnen op de 
drempel van de zoste eeuw, een mijpal kreeg in de jaren zestig met de totstandkoming van een wettelijke regeling en walar nu een nieuw hoofdstuk aan wordt toegevoegd. is het nu slecht voor de beroepsgroep dat sprake is van wettelijk toezicht? Mij dunkt van niet. Wettelijk toezicht is het beste bewijs dat de accountantsprofessie een factor van belang is geworden en ook als zodanig wordt gezien in het Nederlandse maatschappelijk bestel. Positief bezien is dit de krocn op het emancipa tieproces van het accountantsberoep, en, ik zeg het er maar even bij, ik bedoel dat niet cynisch, lk besef me dat veel betrokkenen anders tegen wetteljjk toezicht aankijken. Maar bezien vanuit dit perspectief is de WTA wellicht wat draaglijker.

Ik wil mij in deze bijdrage beperken tot de onafhankelijkheid van de accountant en een enkele opmerking maken over de governance van het accountantsberoep. Ik meen de rechtvaardiging van de keuze van dit thema te vinden in het belang van de accountancy in ons financiele bestel, de rol van accountants bij het wekken van vertrouwen in financiële markten en de discussies daa rover in de samenleving.

Expliciet zij opgemerkt dat naast de onafhankelijkheid van accoun. tants, ook hun deskundigheild en het krijgen van een deugdelijke grondslag voor het maatschappelijk verkeer van groot belang zijn. Sommigen beweren dat de onafhankelijkheid niet het echte probleem van het accountantsberoep is maar dlat de achilleshiel de kwaliteit van de werkzaamheden is. Wellicht, maar ik heb niet de indruk dat in thet maatschappelijk verkeer het beeld leeft van de "naieve accountant", de accountant die niet ziet waar zijn klant mee bezig is. Nee, de afgelopen jaren is verschillende malen in de media het beeld geschetst van de accountant die erbij staat en de andere kant op kijkt. Let wel, ik zeg niet dat dit het geval was, maar wel dat dat beeld werd opgeroepen. ${ }^{2}$ Hoewel de kwaliteit van de werkzamheden van accountants een belangrijk theima is, valt het door tijd gedwongen buiten het bestek van deze bijdrage.

2. As hest gat on de reputatie van de accountant zt hier mins inziens ook de grootste bedreging. Eef accountant die raude of onjulstheder bij de klant nie the eft gezten karn nog we op enige dementie wan het publek rekenen als hij an witlegen watrou dit niet is ontakt Dit is anders woor de accountant die kernis heeft van faude of onjwistheder mar niets met die informatie heft gedaan. 
1.2 De accountant als vertrouwensman van het maatschappelijk verkeer

De accountant heeft zich gepositioneerd als de vertrouwensman van het maatschappelijk werkeer. Zoals reeds door velen beschreven is die vertrouwensman het afgelopen decennium op hardhandige wijze ontsokkeld. Daar waar respect vroeger op woorhand werd gegeven aan zakelijke dienstwerleners moet dat nu worden werdiend. Overigens is de accountant niet de enige professional die verzeild is geraakt in dit proces van ontsokkeling. Zo wordt met politici in satirische programma's de spot gedreven en worden artsen door ontevreden patienten tuchtrechtelijk gedaagd.

Zeker in vergelijking met de Verenigde Staten is in Nederland de kring van controle-plichtige ondernemingen ruim gedefinieerd. Dit betekent dat in Nederland relatief grote wealth transfers plaatsvinden van belanghebbenden bij de onderneming naar controlerend accountants. Door het niet verbieden van non-audit diensten zijn die wealth transfers feitelijk nog groter. Dit gegeven legt een morele druk op de beroepsgroep om na te denken over de werwachtingskloof en over wegen deze te verkleinen. Is de prestatie van accountants substandard dan is wettelijk ingrijpen niet alleen waarschijnlijk maar ook gewenst, mede gelet op het feit dat de bevoegdheid om wettelijke controles uit te voeren exclusief aan accountants is toegekend. Ik hoop dat ik vandaag een bijdrage mag leveren aan het debat over het verkleinen van de verwachtingskloof.

Met uw instemming wil ik gaarne een aantal opmerkingen maken over de onafhankelijkheid wan accountamts.

\section{De onafhankelijkheid van de accountant}

\subsection{Inleiding}

Daar waar de overheid er voor heeft gekozen am de controle van het fiscaal resultaat van ondernemingen zelf ter hand te nemen wordt de controle van de bedrijfseconomische jaarrekening overgelaten aan de markt. De accountant wordt benoemd en betaald door de onderneming maar stalat in dienst van het matschappelijk verkeer. Deze constructie is in het land van de professionele dienstverleners uitzonderlijk. De theorie spreekt over de accountant als agent met twee principalen: de onderneming en het maatschappelijk verkeer 3 Deze constructie draagt

Lie Antle $(1982$ ) en Cassen (1989) voor wite enzettingen over de theorieworming orntrent de posithe van de accountant. Zie Bamberg en $5 p r e m a n n(1989)$ voor meer over de agency theorte. 
op zichzelf al bij aan het ontstaan van een verwachtingskloof lin 1976 schrifft de FNV:4

"Er dient zorg te worden gedragen woor een zo onafhankelijk mogelijke positie van de accountant t.av de onderneming. Daartoe kan gedacht worden aan een onafhankelijk publiekrechtelijk lichoam, dat bedrifsinformatie contraleert, waarbij de beloning wolstrekt is losgemaakt van de opdrachtgever."

Met zoveel woorden uit de FNV haar bezorgdheid over de onafhankelijkheid van de accountant. De FNV had een vooruitziende blik. Nadien hebben ook anderen aandacht hiervoor gevraagd waaronder Professor André Bindenga bij zijn terugtreden bij Ernst \& Young Accountants. 5

2.2 Onafhankelijkheid in fact ws. in appearance: enige empirische resultaten

In de literatuur over de onafhankelijkheid van de accountant wordt onderscheid gemaakt tussen onafhankelijkheid in fact (wezen) en onafhankelijkheid in appearance (schijn). Bij onafhankelijkheid in fact gaat het om het feit dat accountants daadwerkelijk onafhankelijk zijn vain de klant, terwijl het bij onafhankelijkheid in appearance gaat om de perceptie van de onafhankelijkheid zoals die leeft bij ondernemingen en in het maatschappellijk verkeer. De afgelopen jaren zijn er in Nederland diverse studies verricht naar de gepercipieende onafhankelijkheild van accountants. Een onderzoek van het Limperg Instituut in 1987 wees uit dat $53 \%$ van de aandeelhouders, $55 \%$ van de bankiers en $40 \%$ van de ondernemingsraadsleden van mening was dat de accountant onafhankelijk genoeg is van zijn opdrachtgever. lk heb jaren later de vraag opgenomen in een studie onder vakbondsonderhandelaren. Toen bleek $21 \%$ van mening te zijn dat de accountant onafhankelijk genoeg is van zijn opdrachtgever. 6 Dus slechts de helft tot maar een vijfde van de res. pondenten was van mening dat het goed zat met de onafhankelijkheid van de accountant. Mij dunkt dat deze resultaten woor de beroepsgroep reden had moeten zijn om de stormbal te hijsen. Momenteel verricht ik een onderzoek warbij we diverse groepen respondenten de stelling hebben woorgelegd "dat de accountant onafhonkelijk genoeg is van zinn opdrachtgever om met succes te kunnen aandringen op het redresse. ren van directiefraude. Driekwart van de accountants is het eens met

4. FNV (1976, p.g)

5 2ie bijwoorbeld ook Moizer (1991, p.44), Arens en loeberke (2003. p.9ol. Bindenga (2002), Fisher en Quick (2004) en Fileck (2004).

6. Hassink (2000, p. 5.1). 
deze stelling versus $50 \%$ van de commissarissen en siechts $29 \%$ van de belastinginspecteurs. Een zorgelijke score en een dito ontwikkeling vergeleken met de bevindingen wan het Limperg Instituut. Kortom, er zijn zorgen over de onafhamkelijkheid van accountants zoals die wordt ervaren door het maatschappelijk verkee:

\section{Ontwikkelingen in de perceptie van het maatschappelijk verkeer}

\section{1 inleiding}

De relatie wan accountants met hun klanten is over het algemeen goed. Dit blijkt bijvoorbeeld uit de enorme groel die de adviestakken van de grote accountantskantoren in de jaren negentig hebben doorgemaakt. Andere signalen die duiden op een goede relatie is het kleine aantal wisselingen van accountants bij bijwoorbeeld beursgenoteerde andernemingen. Echter, als wordt gekeken naar de relatie van accountants met het maatschappelijk verkeer komt een ander beeld naar voren. Uit de al eerder genoemde studie van het Limperg Instituut uit 1987 bleek dat slechts $26 \%$ van de respondenten wan mening was dat de accountants de pretentie waarmaken dat zij zowel het belang van de te controleren onderneming dienen als dat van derden, 7 Voorts vond toen $87 \%$ van de respondenten dat accountants primair het belang van de onderneming dienen en $16 \%$ dat zij met name in het belang van bankiers optreden.

\subsection{Een aantal woorbeelden}

Mij dunkt dat er sinds 1987 het een en ander is veranderd maar of dit tot gevolg heeft gehad dat het maatschappelijk verkeer nu een meer centrale positie inneemt in de beleving van accountants waag ik te betwijfelen. Ik wil in dit verband een aantal voorbeelden noemen waruit mijn inziens blijkt dat het accountantberoep nog een weg te gaan heeft.

Voorbeeld 1: GBR versus AICPA Code of Ethics

De Gedrags- en Beroepsregels Registeraccountants (GBR) geven in belangrijke mate richting aan het accountantsberoep. De huidige tekst dateert wan 1994 en is gebaseerd op de tekst van 1973. De GBR is de afgelopen dertig jaren het belangrijkste normenstelsel voor accountants in Nederland geweest. Des te opmerkelijker is dat het maatschappelijk verkeer niet wordt genoemd in deze kernregeling. Met

7 timperg Insthutut 1987 p.gol. 
name in het hoofdstuk dat alleen wan toepassing is op accountants die optreden als openbaar accountant zou referentie aan de belangen van het maatschappelijk verkeer niet hebben misstaan. Ik heb de GBR van 1973 er niet op nageslagen maar ik vermoed dat ook daar het matschappelijk verkeer als gebruiker van de accountantsverklaring niet wordt genoemd. Het is opmerkelijk dat de code die gedurende dertig jaren het Nederlandse accountantsberoep richting heeft gegeven, niet expliciet verwijst naar de rol van de accountant ten behoeve van het matschappelijk verkeer. Dit is niet te rijmen met de positie van 'de accountant als vertrouwensman wan het maatschappelijk verkeer'. Is dit een onbeduidende omissie of staat dit symbool voor het gebrek aan expliciete andacht in het accountantsberoep voor de positie en belangen van het maatschappelijk verkeer? of is de focus op de belangen van het maatschappelijk verkeer zo evident dat dit niet in de GBR genoemd hoeft te worden? Net al de IFAC kent de Amerikaanse beroepsorganisatie AICPA deze expliciete focus op de het maatschappelijk verkeer wel. In de Amerikaanse Code of Conduct staat:

"Members should accept the obligation to act in a way that will serve the public interest, honor the public trust.... "(Section 53)

Waar de AICPA in ieder geval op papier de belangen van het maatschappelijk verkeer voorop stellen, kiezen de Nederlandse GBR een heel ander vertrekpunt. In de GBR staat centraal dat de individuele accountant de belangen van de beroepsgroep als geheel niet mag schadlen.

Tabel r: NIVRA GBR en AICPA Code of Professional conduct.

\begin{tabular}{|c|c|}
\hline NIVRA: Gedrags- en beroepsregells & AICPA: Code of Professionall Conduct \\
\hline $\begin{array}{l}\text { De registeraccountant onthoudt zich } \\
\text { wan al hetgeen schadelijk is voor de eer } \\
\text { wan de stand der registeraccountants. } \\
\text { (Art.5) }\end{array}$ & $\begin{array}{l}\text { All who accept the membership in } \\
\text { the American institute of Celtifled } \\
\text { Public Accountants commit themselves } \\
\text { to honor the public frust... (Section } \\
53.04 \text { ) }\end{array}$ \\
\hline
\end{tabular}

Wellicht denkt $u$ dat deze gedragsregel van de AICPA niet bepaald het effect heeft gehad dat het vertrouwen in de Amerikaanse accountant onbeschaamd is gebleven. Dit kan ik alleen maar beamen. Maar een centrale positie van het maatschappelijk verkeer in de belangrijkste 
regeling vain het accountantsberoep onderstreept wel het belang hiervan en kan volgens mij als belief system bijdragen aan een cultuurverandering binnen de beroepsgroep.

Voorbeeld 2: De business principles van een groot accountantskantoor

Een tweede voorbeeld betreft de op de website opgenomen business principles wan een groot accountantskantoor in Nederland (zie tabel 2). Op zichzelf is er niets mis met deze uitgangspunten. Echter, deze principeszijn niet in balans als de accountant wordt gezien als een agent met twee princlpalen. De belangen van die ene principaal (de onderneming) vinden we hierin nadrukkelijk terug, maar de positie en de belangen van die andere principaal (het maatschappelijk verkeer) zijn feitelijk afwezig. Zou het niet goed zijn naast deze business principles op de website ook aandacht te schenken aan het ethische normenkader van de accountant? 8

8. Zie fint (1988) woor een analyse van het normenkader van de accountant. 
Tabel 2. Principes in dienstuerlening op de website van een groot accountantskantoor (oktober 2004)

\section{Principes in dienstverlening}

Onze heldere normen woor kwaliteit en wijze van adviserng, gericht op eem optimale dienstwerlening. Dit zujn ze:

7. Probeer een zo duidelijk mogelijk beeld te knigen van uw cliènten en wan wat 2il verwachten van onze prestaties.

2. Analyseer de behoeften van de cliênt.

3. Formuleer doelstellingen op basis wan de verwachtingen van de client, zodat u uw werk kunt uitworen en aan die verwachtingen kunt woldoen. Stel op basis wan de geformuleerde doelstellingen een cliëntgericht serviceplan op.

4. Voldoe aan uw verplichtingen. Probeer mogeljke hindernissen te voarzien en woorkom irritaties door problemen snel op te lossen. Geef bijzondere aan dacht aan onze integriteitsregels.

5. Streef naar heldere communicatie met uw collega's en collega-kantorer. Het draagt bij aan een goede teamgeest en dus aan een hogere kwaliteit wan onze dienstwerlening, die onze clienten daardoor nog hoger zullen waarde ren.

6. Streef naar heldere communicatie tussen u en uw cliènt Zorg ervoor dat de ciënt zich wan de waarde en de kwaliteit van onze dienstverlening bewust wordt.

7. Lat de client weten war deze aan toe is. Geef helder incicht in cle positie van de onderneming. Gevraagd en ongevraagd.

8. Onderhoud verruim en wersterk de contacten met managers op sleutelposities. Het werstevigt de band met de cliënt en heeft een positieve invloed op de effectiwiteit van de communicatie tussen de cliënt en onze organisatie.

9. Probeer vraagstukken zo snel en goed mogelijk op te lossen. Overleg Hijdig. Handel oprecht en probleemoplossend. En bilff streven naar een werksfeer warin respect voor elkar de basis is.

10. Ceef de client regelmatig de gelegenheid om uw werk ta beoordatan. Op elk niveau wan onze dienstverlening. Het vereist wan uals dienstverlener welswaar ex kwetsbare opstelling - en dat is niet eenvoudig - mat u kunt er de kwallteit wan de dienstwertening mee verbeteren

"1. Zorg ervoor dat hetgeen u aan de clènt declareert, in verhouding staat tot de werkzamheden die u voor uw client hebt verticht. 
Voorbeeld : Ambitie nieuwe topman wan een groot accountantskantoor

De woorzitter wan éen van de grote vier accountantskantoren in Mederand werd onlangs bij gelegenheid wan zijn benoeming geintervewd. Op de warag wat de belangrijkste zaken zijn die spelen woor als bestuurder van de organisatie antwoordt de nieuwbakken bestuurs voorzituers

"Als th er een paar mag noemen: de tevredenheid wan onze medewerkers en clienten, het verder laten groelen wan onze omzet en winst, het externe toezicht op accountantskantoren, de onafhankelijkheid van de controlefunctie, de ongelmiteerde aansprakelijkheid van kantoren, het vaak te negatieve beeld in de media, de werwing wan goede mensen en de werdere inbedding van onze organisatie in onze Europese organisatie."

Het dienen van de belangen van het maatschappelijk verkeer en de ambitie om krachtig bij te dragen aan het herstel wan publiek vertrouwen vinden we hierin niet terug. Wel de zorg om de tewredenheid van medewerkers en clièten en de wens om omzet en winst te laten groelen. In ieder geval zijn deze laatste twee doelen niet in het belang wan het maatschappelijk verkeer.

Hoevel de accountant zichzell ziet en positioneert als vertrouwensman wan thet maatschappelijk verkeer zijn er allerlei aanwijzingen dat het matschappelijk verkeer toch een minder centrale posithe inneemt in de belevingswereld van de accountant dan gewenst. Om dit te veranderen is een cultuurverandering noodzakelijk en die cultuurverandering moet worden geinitieend door de leiders van het beroep.

\subsection{Nieune ontwikkelingen}

Zijner nu ook positieve ontwikkelingen? Zijn er aanwijzingen dat het maatschappelijk werkeer beter op de kaant komt te staan? Ja, en ik wiler een aantall noemen.

\section{Focus Mraba-bestuur}

zoals gezegd, de leiders wan het beroep dienen de noodzakeijke cultuurverandering te initieren. Het Nivra-bestuur beseft dat het malatschapelijk verkeer op de eerste plats komt en spreekt dat ook helder uit. Niva woorzitter Van de Wel merkt in het jaamerslag 2002/2003 op: ${ }^{10}$

9 Ze De Accountant, Oktober 2004, p.78.

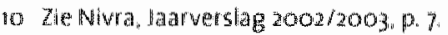


"We rediseren ans als geen ander dat het maatschappelijk verkeer onze belangrijkste klant is."

Dit is een indicatie van een nieuwe wind binnen de beroepsorganisatie. In ieder geval is de public relations verbeterd en dit draagt bij aan de verkleining van de communicatiekloof.

\section{Instelling Raad van Advies}

Het Nivra-bestuur kan echter niet volstaan met op te merken dat het maatschappelijk verkeer de belangrijkste klant is en de public relations verbeteren, inaar moet daar wervolgens invulling aan geven door verder beleid te maken. Een begim is gemaakt. Op 25 juni 2003 heeft het Nivra een Raad van Advies ingesteld. Het Nivra zegt daarover:"

"om het maatschappelijk verkeer een prominente stem te geven binmen het Nivra is in mei 2003 een Raad van Advies ingesteld als klankbord voor bestuur en directie."

Deze Raad van Advies bestaat uit vier personen waarvan drie voormalige top-CEO's. Het geheel staat onder woorzitterschap van een registeraccountant. De status en doelstelling van dit gremium blijken niet uit het jaarverslag. Bij de samenstelling van deze adviesraad, met name dat drie vam de vier leden ex-CEO zijn, kan wraagtekens, worden gezet als de doelstelling is om het maatschappelijk verkeer een stem te geven. maar het is hoe dan ook een begin. Overigens is onduidelijk in hoeverre en welke soort thema's besproken zijn met dit college. Het jaarverslag 2003/2004 van het Nivra vermeldt niets over de werkzaamheden van de Raad wan Advies.

\section{De accountont in de algemene vergadering wan aandeelhouders}

Een andere positieve ontwikkeling betreft de aanwezigheid van de accountant op de algemene vergadering van aandeelhouders. Weliswar is dit de resultante van een ontwikkeling buiten thet accoun. tantsberoep, het effect is er niet minder om. ${ }^{2} \mathrm{lk}$ denk overigens niet dat het belang van deze ontwikkeling primair zit in de toegevoegde waarde die de accountant ter plekke in de algemene vergadering van aandeelhouders heeft. ik werwacht dat hij in de praktijk vooral zal lave. ren tussen de belangen van de ondermeming, die van zichzelf en die van

11 Zie Nivit jar versiag $2002 / 2003$.

12. Dil wind zijn oorsprong in de Code Tabaksblat. 
het maatschappelijk verkeer, maar misschien ben ik te pessimistisch, de tijd zal het leren. Nee, ik denk dat de aanwezigheid van de accountant op de algemene vergadering van aandeelhouders vooral van belang is voor de accountant zelf. De accountant wordt letterlijk geconfronteerd met het maatschappelijke verkeer, zijn opdrachtgever. Het anonieme maatschappelijke verkeer krijgt een gezicht en een stem. Het effect hiervan in psychologische zin is mijn inziens niet te onderschatten en warschijnlijk veel groter dan de gevolgen die het heeft in materiele zin voor de wragenstellende aandeethouder. Overigens heb ik bedenkingen bij de beleidslijn die één van de vier grote accountantskantoren terzake heeft. Ik citeer: 13

"en zolang de vennootschap de accountant niet vraagt om aanwezig te zijn, blijft hij weg, zo is de beleidslijn".

Mij dunkt eer wat merkwaardig uitgangspunt van de vertrouwens* man van het maatschappelijk verkeer en ook lastig te rijmen met de eerder aangehaalde uitspraak van de Nivra-voorzitter dat "we ons realiseren dat het maatschappelijk verkeer onze belangrijkste klant is".

3.4 Magelijke verklaringen voar de beperkte aandacht voor de positie van het maatschappelijk verkeer

I heb aangeven dat de relatie van de accountant met het maatschap. pelijk verkeer een moeizame is. Hoe is dat zo gekomen?' Het is niet zo eenvoudig antwoord te geven op deze vraag. Toch een poging daartoe. Een eerste mogelijke verklaring is dat naarmate een beroepsgroep beter is georganiseerd de neiging lijkt te ontstaan meer in eigen kring af te doen. Het accountantberoep is van oudsher goed georganiseerd. Een tweede verklaring is dat naar mate de materie technischer wordt, de tendens ontstaat buitenstaanders niet te betrekken bij de besluitworming met het idee dat zij te ver van de materie afstaam om een zinvolle bijdrage te kunnen leveren aan de discussie. Een beroep dat zich bedient van jargon met kreten als materialiteit, axiomatisch voorbehoud en

13 Decountant Aprill 2004, p.45.

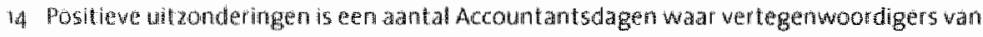
het matschappelijk verker gewragd werd hut visie te geven (zik biboorbeeld Kok.

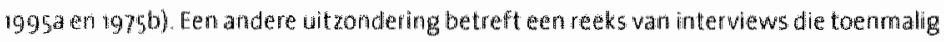
Niva voonthter profdr. A. Schilder theft gehouden met diverse groapen in de samen.

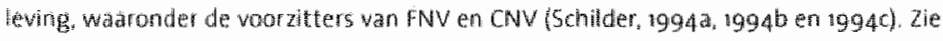
ook di bijargen wan Westerialken 1989 ) en Stekelarburg (1995). 
professional judgement en die begrippen ook als absolute waarheden ziet, nodigt niet uit tot discussie. Een derde verklaring woor de relatieve introverte houding van het accountantsberoep is het gebrek aan vers bloed in de bedrijfstak. Carrierepaden binnen accountantskantoren hebben een typisch up-or-out karakter. 15 Aan de basis komt vers bloed in de organisatie in de vorm van afgestudeerden van universiteiten en hogescholen en vervolgens begint het lange proces van sociale inllij. ving. Dit betekent dat de top van accountantsorganisaties bestaat uit accountants die vaak al decennialang alan de eigen organisatie verbonden zijn. Zij-instroming van andere accountantskantoren of van buiten de bedrijfstak komt op dit niveau zelden voor. Ook op het allerhoogste niveau doet dit verschijnsel zich voor. De raden van bestuur van de grote accoumtantskantoren worden typisch bemand door eigen kweek. dat will zeggen door partners die al een half werkzaam leven of langer aan de organisatie verbonden zijn. Dit benoemingsbeleid versterkt enorm de cultuur van het individuele accountantskantoor en creëert een infrastructuur waarbij sommige zaken als vanzelfsprekend worden beschouwd en dus niet ter discussie worden gesteld. Ook om andere redenen bevordert dit up-or-out-proces niet het krachtdadig optreden van besturen van accountantsorganisaties. Dit selectieproces maakt het onwaarschijnlijk dat er een aanwoerder komt waarvan de oudit portners het vermoeden hebben dat hij heilige huisjes omver zal trappen. ${ }^{16}$ it effect wordt nog erger als bestuurders hum eigen klanten blijwen bedienen tijdens hun termijn als bestuurder of na verloop van tijd terugkeren naar de front office en als audit partner verder gaan. In dat geval hebben zij zelf ook geen belang bij een al te stevig optreden omdat ze dan als audit partner met de gevolgen geconfronteerd wordem. Dit beleid zorgt voor continuiteit en borging van de cultuur. Op sommige dossiers en op sommige momenten in de tijd, met name daar waar draagvlak binnen het beroep belangrijk is, heeft dit business model zeker zijn voordelen. op andere momenten darentegen, met name daar waar de omgeving heftig in beweging is en een krachtig antwoord moet worden geformuleerd heeft dit model duidelijke nadelen.

15 Matjoor (1995) heeft in zinn oratie eer economische analyse wan het 'up -ol-out' system binnern accountantskantoren gegeven en heeft wooral do economische woordelen voor organisatie en individuele arcount ant besprokem.

16 Daar komt bij dat de traditie om alleen leiders uit eigen kring op het schild te tilen

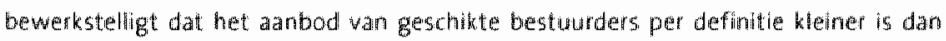
wanneer ook buiten de eigen organigate bestumlifk talent angeboord kan worden. 


\section{Standlard setting in auditing}

Gaarne zou ik nu een paar opmerkingen willen plaatsen over het proces van het ontwikkelen van controlestandaarden woor accountants.

\subsection{De theorie van standard setting}

In de economische literatuur worden twee theorieen beschreven die de totstandkoming van regelgeving proberen te verklaren: de public interest theory en de private interest theary. De public interest theory veronderstelt dat regelgeving ten doel heeft de sociale welvart te maximaliseren. Regelgeving is in dit perspectief de resultante van eien maatschappelijke vraag om marktfalen te corrigeren. Feitelijk de uitwerking van de gedachte 'De vervuiler betaalt'. De gedachte van de private interest theory is dat groepen belanghebbenden lobbyen om hun eigenbelang te behartigen. Partijen proberen economische voordelen oftewel, wealth tronsfers te realiseren. Als door regelgeving als zodanig geen extra waarde wordt gecreëerd gaan de economische voordelen voor de ene partij ten koste van één of meerdere andere partijen. Bij elk onderwerp hebben partijen de mogelijkheid te lobbyen. De keuze om wel of niet te lobbyen is een functie van de verwachte kosten en voordelen die gepaard gaat met een succesvolle liabby.7

\subsection{Standard setting in accounting en auditing}

Een van de gebieden waar deze theorieën zijn gebruikt om de ormang en aard van de regelgeving te bestuderen is de externe verslaggeving oftewel de financial accounting. Een hele stroom wan onderzoek houdt zich bezig met de vraag of en hoe ondernemingen, gebruikers. van jaarrekeningen en accountants hebben gereageerd op voorgestelde verslaggevingsregells. Inmiddels is dan ook veel kennis vergaard op dit terrein ${ }^{18}$

Heel anders is dit op het gebied van de richtlijnen woor de accountantscontrole, oftewel auditing stondards. ${ }^{19}$ Deze richtlijnen bepalen waar accountants zich tijdens hun werkzaamheden aam dienen te houden. Dit betreft bijvoorbeeld hoe accountants hun werkzamheden die-

17) Zhe Georglou 2002, p.700).

18 Zhe bijuorbeeld Watts en Zimmerman (1986 en 1990), Georghow (2002), Thorley Hill ef at. (2002).

19 In Nederland zijn dit oa de Richtlinen voof de Accountantscontrole (RAC) (Nivra. 2003 तो). 
nen te plannen, hoe zij met aanwijzingen van fraude dienen om te gaan en hoe zij gebruik kunnen maken van de werkzaamheden van anderen. Zo omvangrijk als de wetenschappelijke literatuur ower lobbygedrag in het geval van verslaggevingsregels is, 20 beperkt is de literatuur over lobbygedrag ten aanzien van auditing standards. 20

Mij dunkt dat eerder genoemde public en private interest theory niet alleen van toepassing zijn op het proces wan het ontwikkelen van verslaggevingsregels maar zich mutatis mutandis ook lenen om het proces van het ontwikkelen van auditing standards te analyseren.

De afgelopen veertig jaar zijn auditing standards door het beroep ontworpen, dat wil zeggen door accountants zelf. Overigens geldt dit ook voor de controle op de naleving daarvan, maar dit terzijde. Voor een deel worden deze regels op international vlak ontwikkeld door partijen als IFAC / IAASB en voor een deel in het nationale domein door de beroepsorganisaties, die overigens zelf weer deelnemen in het IFAC. Derhalve is ten aanzien van het ontwikkelen van auditing standards feitelijke sprake van zelfregulering, zowel in het internationale als nationale dome in. De situatie in Nederland bestaat, althans in gecodificeerde zin, sinds het van kracht worden van de Wet op de Registeraccountants van 1962. De WRA geeft het Nivra het expliciete recht zelf auditing standards uit te vaardigen. Dit betekent dat het maatschappelijk verkeer geen noemenswaiardig rol heeft gespeeld bij de totstandkoming van awditing standards.

Mij dunkt dat zelfregulering de meest extreme worm is van het private interest model. Dit model van het ontwikkelen wan regelgeving biedt het beroep buttengewone mogelijkheden om voor haar gunstige regels te realiseren. Om een aantal redenen. Op de eerste plaats omdat zowel langs officiële als officieuze weg de beroepsgenoten de eigen beroepsorganisatie goed weten te vinden om aldaar hun belang te bepleiten. Op de tweede plats hebben de standard setters zelf ook belang bil de uitkomsten van het standard setting proces amdat ze twee petten dragen, die van standard setter en gebruiker wan de auditing standards. Critici zullen zeggen dat deze constellatie het niet warschijnlijk maakt dat auditing standards worden geaccepteerd die in het belang zijn van controleklanten of het maatschappelijk verkeer ma ar die sterk indruisen tegen het belang van accountants. Op de derde plats speelt dat de 
standard setter niet alleen de aard van de auditing standards bepaalt maar ook de regie woert over het standard setting process zelf. Dus de vraag of en hoe het maatschappelijk verkeer wordt betrokken bij het ontwerper of aanpassen van auditing standards wordt beantwoord door het beroep zelf. In de praktijk betekent dit dat het maatschappelijk verkeer nauwelijks wordt betrokken bij het ontwikkelen van auditing standards. lk denk dat dit een ongewenste situatie is en in mijn ogen ligt hier een belangrijke taak voor de overheid maar daarover later meer. ${ }^{21}$

\subsection{Voorbeelden van zelfregulering van auditing standards}

Ik will vier voorbeelden noemen wan zelfregulering van auditing standards waar wellicht met meer transparantie en inbreng van het maatschappelijk werkeer tot andere besluitvorming was gekomen. De eerste drie woorbeelden zijn ontleend aan de Nadere Voorschriften inzake Onafhankelijkheid van de Accountant.

\section{Voorbeeid: Scheiding wan controle en advieswerkzaamheden}

De schijin van onafhankelijkheid wordt negatief beinvloed doordat accountants aan controlecliënten ook adviesdiensten verstrekken. De "Nadere Voorschriften" maken bepaalde combinatties van controle- en adviesdiensten weliswaar lastiger maar staan andere combinaties expliciet toe. Zo wordt niet uitgesloten dat accountants belastingadvies kunnen geven aan controleklanten.2z Dit brengt een aantall risico's met zich. Behalve het financiële belang speelt dat ondernemingen van belastingadviseurs verlangen dat deze het maximale uit het vuur slepen. De belastingadviseur zal dan ook wakk de randen opzoeken van hetgeen fiscaal geaccepteerd is. Van de accountant als controleur van de jaarrekening met daarin verwerkt de fiscale positie wordt een objectief oordeel verwacht over het geheel. Ook indien het belastingadvies formeel wordt gegeven door een collega uit de belastingpoot van het eigen kantoor ontstaat een spanningsveld. De controlerend accountant komt dan in de positle dat hil een oordeel moet geven over het advies van een kantoorgenoot. Hier schuilt een groot risico van verlies van onafhankelikheid. Het verkopen van agressieve taxshelters aan contro-

21 Owerigens warpt dit nog wel een bijzonder licht op thet tros poltica argument wat crithich van de WTa zich wan hebben bediend. Het inticme kataker van het proces wan totatandkoming bar awditing standords en to zeht in de vorm van de CTK was de afge. lopen jaren nijns mztens ook bepald geen schoolwoorbeald baln trios politico.

22. Zle Nivra $\left(200 \mathrm{gb}_{\mathrm{n}} \mathrm{p}-3 \mathrm{3}\right)$. 
leclienten, hetgeen blikbaar niet alleen in de Verenigde Staten maar aok in Nederland gebeurt, maakt het risico nog groter. 23 in de verenigde Staten speelt deze discussie ook. Zo heeft Calpers éen van de grootste pensioenfondsen van de VS het gemunt op ondernemingen waarbij de accountant tevens belastingwerk verricht: 24

"The red flags we're looking at are tax planning, tax audits, and tax consultations Calpers believes they represent a conflict of interest."

Vertegenwoordigers van het maatschappelijk verkeer hebben door het standard setting process niet de kans gekregen zich te uiten over de combinatie van controle- en belastingadvies. Onduidelijk is dan ook of het maatschappelijk verkeer van mening is of deze combinatie van werkzaamheden moet worden verboden, dan wel of in deze situatie additionele eisen aan de accountaint moeten worden gesteld.

Voorbeeld 2: Openbaarmaking van inkomsten wit controle en advies

Anders dan bijvoorbeeld in de Verenigde Staten, het verenigd Koninkrijk en in Australië schrijven Nederlandse regels niet voor dat de hoogte en samenstelling van het accountants.honorarium in het jaarrapport openbaar gemaakt moeten worden. ${ }^{25}$ Uiteraard kunnen ondernemingen op wrijwillige basis deze informatie in de jaarrekening verstrekken. Er zijn echter maar weinig ondernemingen in Nederland die dit doen en als verslaggevingsregels niet eisen dat ondernemingen informatie over de hoogte en samenstelling van het accountantshonorarium openbaar moeten maken kan de accountant dit ook niet van de ondermeming eisen. Het Nivra heeft accounting standard setters opgeroepen om op dit punt met dwingende voorschriften te komen. ${ }^{26} \mathrm{Mij}$ dunkt dat het beroep hier een kans laat liggen. Het zijn immers niet de ondernemingen maar de accountants die op het onafhankelijkheidsdossier aan herstel van vertrouwen dienen te werken. Om die reden zou het accountantsberoep het initiatief naar zich toe moeten trekken. De enige plek in het jaarrapport waar de accountant de regie voert is de accountantverklaring. Waarom niet de tekst van de accountantsverklaring uitbreiden met informatie over het accountantshonorarium? De beroepsorganisatie zou via aampassing van de voorgeschreven teksten

23 Zie De Accountant. April 2004, p. 24 .

24. Zie CFO, luni 2004. p. 24.

25 Deze paragrat is ontleend aan Hassink (2003)

26 zie Niva, Nadere Voorschriften inzake da Onafhankellijkheid vande Accountant, pro. 
van de verschillende accountantsverklaringen aan har leden kunnen opleggen dat zij zelf in het jaarrapport van hun clienten informatie verstrekken over de hoogte en samenstelling van het honorarium, gesplitst naar controle- en adviesdiensten. Waarom is het accountantsberoep niet hiertoe overgegaan? Wellicht was dit anders geweest als het matschappelijk verkeer was betrokken in het stondord setting process. Als het maatschappelijk verkeer met dit argument was gekomen had het Nivra in haar bosis for conclusions een standpunt hierover moeten innemen.

Woorbeeld 3: Zelftoetsing in Nadere Voorschriften

Een te lange zakelijk relatie tussen de accountant en de onderneming kan een bedreiging vormen woor de onafhankelijkheid van de accountant. Verplichte rotatie van de accounitant wordt vaak genoemd als instrument om te voorkomen dat een te grote mate van vertrouwdheid met de klant ontstaat. Audit partners bij public interest entities mogen maximal zeven jaar bij een opdracht betrokken zijn. 27 De Nadere voorschriften zeggem hierover:

"Een te grote mate van vertrouwdheid of vertrouwen kan een bedreiging vormen woor de onafhankelijkheid wan de accountant w...woral wanneer het gaat om controleclienten die als public interest entity worden aangemerkt."

Ik vraag me af of dit risico groter is bij public interest entities dam bij andere ondernemingen. Mijl lijkt van niet. Over andere ondernemingen zeggen de Nadere Voorschriften: 28

"Indien bij controlecliënten die niet als public interest entity kunnen worden aangemerkt, geen systeem wan interne roulatie kan worden gecreëerd (bijwoorbeeld door amvang van de desbetreffende accountantsorganisatie) "kan worden overwogen binnen een redelijke periode (zeven jaor) het dossier te laten beoordelen door een externe accountont, dan wel minstens advies in te winnen bij de beroepsorganisatie."

Critici zouden kunnen beweren dat wanneer het accountantskantoor te klein is om tot interne roulatie over te gaan het belang van de accountant blijkbaar zwaarder weegt dan het borgen van diens onafhankelijk. heid. Als het maatschappelijk verkeer was betrokken bij het standard

27 Nivra, 2002, Nadere Voorschiften inzake de Onathankelijkheid van Accountarsts. p.25. 28 Nivra, 2002. Nadere Voorschriften inzake de Onathankelikheid van Accountarts, 0.25 
setting process. was de mening van het maatschappelijk verkeer duidelijk geworden en had dit mogelijk geleid tot een andere tekst.

\section{Voorbeeld 4: Absolute formulering van geheimhoudingsplicht}

in de huidige GBR is zwaar ingezet op geheimhouding. De GBR ver. langen van de accountant dat hij zaken die hem tijdens de uitoefening van zijn werkzaamheden ter ore zijn komen woor zich houdt. Er zijn wellicht situaties denkbaar dat geheimhouding in het belang is van zowel onderneming als maatschappelijk verkeer. Geheimhouding kan echter ook indruisen tegen het belang van deze laatste.29 Het is de vraag of de wijze warop geheimhouding in de CBR is verankerd recht doet aan de functie 'vertrouwensman van het maatschappelijk verkeer'. Critici zullen wellicht beweren dat door het belang dat aan geheimhouding wordt toegekend de accountant meer de vertrouwensman van de ondernemingsleiding lijkt. Mogelijk dat bij een transparant proces waarbij het maatschappelijk verkeer expliciet de mening had kunnen geven over het belang van geheimhouding en over de omstandigheden waaronder de accountant wordt ontslagen van geheimhouding tot een ander voorschrift was gekomen dan thans het geval is.

Tot zover mijn voorbeelden van uitwerkingen van zelfregulering. Gaarne zou ik nog een paar opmerkingen maken over de positie en status van IFAC.

\subsection{Positie en status van IFAC}

De EU en AFM lijken IFAC en de ISA's te accepteren als normenkader voor accountants. Europese of zelfs mondiale harmonisatie of stan. daardisatie van auditing standards is op zichzelf een goed streven. Toch hoop ik dat de EU en AFM met reserve ISA's zullen overnemen. Hoe je het went of keert, het IFAC is de stem van het mondiaal georganiseerde accountantsberoep. De IAASB heeft geen zelfstandige of in leder geval een onduidelijke positie onder de IFAC paraplu en in die zin zijn ISA's niet meer en minder dan een compromis van het accountantsberoep. die weliswar gezaghebbend zijn maar wel uil de koker wan het beroep komen.

29. If verwijs hierbij maar de rol van instellingsaccountants in het kader wan de HBO fraude warbij zij zich betiepen op hun geheinhoudingspilicht om te yookkomen dat inzage in dossiers moest worden gegeven (De Accountant, Mei 2004. P.7). 
Naast het feit dat IFAC de stem van het georganiseerd beroep is, speett er nog een ander probleem dat overigens hieraan gelieerd is. Dat is het gebrek aan legitimiteit buiten het beroep en dit is in mijn ogen een vel fundamenteler probleem. Het maatschappelijk verkeer weet de weg naar IFAC maar moeilijk te vinden met als gevolg dat onduidelijk is of en op welke wijze de meningen van het maatschappelijk verkeer zijn betrokken in het proces van het totstandkomen van de $15 \mathrm{~A}^{\prime} \mathrm{s}$. I w wil dit illustreren met het wolgende voorbeeld. In 2003 heeft IFAC de Exposure Draft van de nieuwe geformuleerde Code of Ethics for Professional Accountants uitgezet. Een van de belangijikste standaarden. In totaal zijn volgens de IFAC's website30 38 reacties binnengekomen; 27 van IFAC lleden (waaronder de reactie van Nivra), vier van accountantsorganisaties $3^{31}$ en zeven van het maatschappelijk verkeer waaronder één van IFAC Education Committee, en éen van FEE, dus beidle feitelijk ook van het beroep. De enige reactie die afkomstig is van gebruikers van jaarrekening met een significante achterban is de reactie van het Basel Committee on Banking Superwision.32 $\mathrm{k}$ concludeer hieruit dat het brede matschappelijke verkeer het IFAC niet of nauwelijks weet te vinden. Als zelfs op het ontwerp van de kernfegeling wan het accountantsberoep nauwelijks wordt gereageerd valt het te betwijfelen of dit wel het geval zall zijn bij de meer technische onderwerpen. Derhalve moeten vraagtekens worden gesteld bij de legitimiteit van IFAC en is IFAC niet minder maar ook niet meer dan de stem wan het georganiseerde accountantsberoep en tenzij IFAC er in slaagt om draagvlak te verwerven buiten het beroep is dit in mijn ogen een wel erg smalle basis om ISA's zondermeer verplicht te stellen als auditing standards voor Europese accountants. Overigens wordt inmiddels in IFAC verband gewerkt aan de Public interest Oversight Board (PIOB) een klankbord waarin vertegenwoordigers van het maatschappelijk verkeer zitting zullen nemen. Onduidelijk is wat de rol wan de PIOB zal zijn, met name ook ten aanzien van de $15 A$ 's die reeds wan kracht zijn. verder kan in mijn agen de PIOB wel de legitimiteit van ISA's verhogen

30 2le whwiflacorg

31 Detoitte, E\&Y, Grant Thornton en PWC

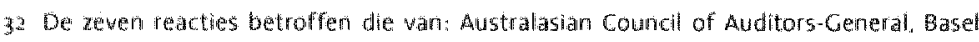
Committee on Banking Superwision. Dutch Informal Group. Federation des Experts Complables Europeens (FEE). IFAC Education Committee, Jean Bechard, National Association of state Boands of Accountancy (NA5BA) 
maar nooit de inbreng van het brede maatschappelijk werkeer ter zake compenseren 33

Gelet op bovenstaande opmerkingen kunnen 1SA's prima fungeren als ondergrens voor auditing standards in Nederland. Maar er zijn mijns inziens nog onvoldoende garanties dat ISA's in voldoende mate tegemoet komen aan de eisen van het maatschappelijk verkeer.

\section{Aanbevelingen}

\section{1 inleiding}

Op basis van de analyse die ik u heb alangeboden kom ik tot de volgende aanbevelingen.

\subsection{Beroepsorganisatie: Nivra}

Zoals aangegeven is de politiek in Nederland genereus geweest als het gaat om het waststellen van de kring wan ondernemingen die vallen onder de wettelijke controleplicht. Dit verplicht de beroepsgroep kwaliteit te leveren en onafhankelijkheid te garanderen ook woor wat betreft de controle van de niet-public interest entities, dus in het geval van heel veell grote en alle middelgrote ondernemingen. Bij de controle van organisaties van maatschappelijk belang de hoogste onafhankelijkheidseisen aan de accountant stellen is een begin, maar niet meer dan dat. Ook gebruikers van jaarrekeningen van niet-public interest entities dienen te kunnen vertrouwer op de onafhankelijkheid van de accountant. Dit betekent in mijn ogen dat de Nadere Voorschriften Onafhankelijkheid op onderdelen uitgebreid en aangescherpt dienen te worden. Individuele accountants en kantoren die daar niet aan kunnen of wensen te voldoen kunnen of afscheid nemen van het marktsegment van de wettelijke controle of aansluiting zoeken bij een groter verband. Dit zal ongetwijfeld leiden tot een concentratietendens maar uiteinde. lijk is de onafhankelijkheid van de accountant hiermee gediend.

Een beroepsgroep van maatschappelijk importantie dient uiterst zorgvuldig om te gaan met het haar gegeven recht tot zelfregulering. Daarbij hoort in leder geval een transparant besluitvormingsproces waarbij het maatschappelijk verkeer in alle stadia wordt betrokken en de mogelijkheid krijgt feed back te geven op woorgestelde auditing

33 Overigens geldt ditzelfde woor de endorsement wan ISA's door $105 \mathrm{CO}$ 
standards. Ook hoort daarbij dat verantwoording wordt afgelegd over de uiteindelijke keuzes. Deze transparantie begint al met het samenstellen van de Nivra-commissies die voorbereidende werkzaamheden verrichten. Het Nivra zou moeten overwegen om werkgroepen die zich met kritische dossiers bezig houden pluriformer samen te stellen. Zo zou het voor de Niwra-commissie Onafhankelijkheid goed zijn om deskundigen van buiten de beroepsgroep uit te nodigen zitting te nemen in dit gremium. Ook de optie orn met bijvoorbeeld de AFM te komen tot de oprichting van een Nederlandse tegenhanger van de PIOB woor specifieke Nederlandse auditing standards is het overwegen waard. De nieuwe GBR en de Verordening op de Fraudemelding vormen voor het standard setting process aardige testcases.

Een laatste aspect betreft het belang van heldere communicatie naar het maatschappelijk werkeer. Accountants wekken vaak de indruk financiële alleskunners, te zijn, en daarbij will het onderwerp van de forensische accountancy als voorbeeld aanhalen. Enerzijds wekken accountants op dossiers die wekenlang voorpaginanieuws zijn de indruk dat zij elke fraude boven tafel kunnen krijgen waarbij partijen elkaar in de haren vliegen over declaraties van honderden euro's, en op andere momenten, bijvoorbeeld bij de Enquête Bouwfraude beweert de accountant niets met de fraude te hebben gedaan omdat deze niet materieel was. Dergelijke voor het publiek conflicterende boodschappen zijn niet wit te leggen en dragen disproportioneel bij aan de verwachtingskloof. Het is goed dat het beroep hier actie heeft ondernemen in de vorm van de Richtlijn Persoonsgebonden Onderzoek. Wat niet goed is dat deze pas is geformuleerd nadat de schade is aangericht. Een meer pro-actieve houding had dat kunnen woorkomen. Door in een vroeg stadium in debat te gaan met het maatschappelijk verkeer en partijen expliciet uit te nodigen te reageren op concepten van auditing standards wordt de kans op maatschappelijk ongenoegen en reputatieverlies op een later moment verkleind.

\subsection{Accountantskantoren}

Binnen accountantskantoren geldt dat bestuurders vaak al decennia bij de eigen organisatie werkzaam zijn. Het gevaar bestaat dan dat de zelfreflectie verdwijnt. Voorts leiden de organisatie- en beloningsstruc. tuur tot een sterke focus op het hier en nu. De afgelopen decennia hebben uitgewezen dat dit vamuit financieel perspectief een goede strategie was. Dit organisatiemodel leidt echter ook tot re-actieve topbestuurders 
en daarmee tot een beroepsgroep die "achter de feiten aanrent". Ik denk dat het goed zou zijn als accountantskantoren over hun eigen schaduw springen en hun organisatiestructuur en belonings- en selectiebeleid van hun leiders eens tegen het licht zouden houden.

Een tweede aspect dat beter kan betreft de communicatie over de verbeteringen die accountantskantoren inmiddels hebben gerealiseerd. Ik heb namelijk stellig de indruk dat accountantskantoren de afgelopen jaren belangrijke stappen hebben gezet om hun onafhankelijkheid te vergroten en hun corporate governance structuren te verbeteren. Ik denk niet dat kantoren er al zijn, maar er is zeker vooru itgang geboekt.34 Des te opmerkelijker is dat hiervan weinig is terug te vinden op bijvoorbeeld de websites en jaarverslagen van accountantskantoren, zo ongeveer de enige bronnen met betrekking tot accountantskantoren die toegankelijk zijn voor maatschappelijk verkeer. Wat bijvoorbeeld opvalt is dat met name de websites van de grote vier accountantskantoren uitsluitend gericht zijn op het werven van nieuwe klanten en niet gebruikt worden als platform om de relatie met het maatschappelijk verkeer te duiden en te verbeteren. I moet hier aan toevoegen dat het Nivra dit a anmerkelijk beter doet. Overigens heeft een van de grote vier accountantskantoren een uitvoerige Code of Conduct voor haar medewerkers op de website st.aan waarin belangrijke kernwaarden als integriteit en onafhankelijkheid worden uitgewerkt. Het openbaar maken van een dergelijk belief system kan een belangrijke bijdrage leveren aan het werkleinen wan de verwachtingskloof. Toezicht op naleving, sancties en openbaarmaking van de resultaten hiervan, dragen verder bij tot gewenst gedrag en verkleinen van genoemde kloof.

\subsection{Toezichthouder: AFM}

in de WTA lijkt de keuze te worden gemaakt woor continuering van zelfregulering door de beroepsorganisaties, zil het onder toezicht wan de AFM. De keerzijde van zelfregulering is transparantie. De AFM zou er op toe moeten zien dat de beroepsorganisaties transparant zijn in elke fase van het regelgevend proces; bij het ontwikkelen van richtlijnen, het uit-

34. Interessamt in dit verband is om de jar verslagen van de grote vien acount antskantoren

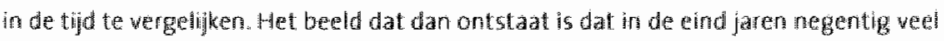
dandacht was woon full service concept, groei en het halen wan ambitheuze dow stellingen terwill in de jaarverslagen wan de afgelopen jaren al meen is terug te vilnden over he debat in de samenleving an het belang van ethische wa atden woor accountats. 
nodigen van derden om daarop te reageren en het openbaar maken van de reacties op de websites van de beroepsorganisatie. Ook zouden definitieve versies van belangrijke richtlijnen gepaard dienen te gaan met een uitvoerige bosis for conclusions met expliciete werwijzing naar de binnengekomen commentaren. De ophanden zijnde aanpassingen van de Gedrags- en Beroepsregels en de Verordening op de Fraudemelding zijn geschikte test cases.

\subsection{Gebruikers van de accountantsverklaring}

De verwachitingskloof in de accountancy is al door velen gedocumenteerd. Het is niet faur de verwachtingskloof in zijn geheel toe te schrijveri aarin de substandard performance van accountants. Een deel van de verwachtingskloof is de resultante van onrealistische verwachtingen die leven aan de kant van het maatschappelijk verkeer, ik werwijs naar de studie van Porter (1993) die in dit verband spreekt over unreasonable expectations en de reasonableness gap. Het oordeel over de accountant wordt snel geveld. Mocht er een mogelijkheid komen om actief te participeren in het standard setting process, grijp die kans dan ook aan. Ook de algemene vergadering van aandeelhouders biedt een interessant platform om in direct contact met accountants te komen. Maak daarvan gebruik. Wees kritisch maar probeert $u$ zich ook te verplaatsen in de positie van de accountant.

\subsection{Universiteiten}

Universiteiten dienen zich nog meer te beseffen dat de toekomstige leiders van het accountantsberoep vandaag in de onderwijsgroepen zitten. Het verder scherpen van een kritische houding is minstens zo belangrijk als het stampen van richtlijnen. Met cases, rollenspellen en gastsprekers uit het accountantsberoep en het maatschappelijk verkeer kan deze houding worden aangekweekt. Deze inspanningen zullen echter weinig effect resulteren als vanuit de beroepsgroep en vanuit de kantoororganisaties het bediscussiëren van de "partijlijn" niet wordt gestimuleerd of nog erger niet wordt getolereerd. Als signalen niet consistent zijn komt een cultuurverandering niet tot stand.

\subsection{Studenten}

Ik heb ook nog een boodschap voor de studenten van de postdoctorale opleidingen, in het bijzonder die tot accountant. $U$ bent allen vrij recent toegetreden tot een accountantsorganisatie; $u$ bent het verse bloed waarover ik sprak. Als opleiding beseffen wij dat $u$ de leiders van 
overmorgen bent. En ook al zit u nu in het lange proces van socialisering in uw organisatie, graag wil ik u voorhouden dat het wel degelijk mogelijk is om tegelijkertijd én loyaal én opbouwend kritisch te zijn richting uw eigen organisatie en het beroep waarin u werkzaam bent.

\section{Afsluiting}

Als er niet over de accountant wordt gesproken zijn de accountant en zijn professie geen factoren wan belang. Juist het feit dat daarover wordt nagedacht en gediscussieerd tekent de relevantie van de accountancy in ons maatschappelijk bestel. Het recente opschudden wan het bed is daarvan een uiting. De wetenschap heeft zich nog teveel afzijdig gehouden in het diebat omtrent de nut, noodzaak en invulling van de WTA. Ik heb met deze oratie geprobeerd een bescheiden bijdrage te leveren aan de governance en onafhankelijk van het accountantsberoep. Het was niet mijn bedoelling een somber beeld te scheppen. Wel was het mijn intentie om een kritisch maar opbouwend bedoeld geluid te laten horen.

Auditing is een interessante tak van sport omdat wetenschap. praktijk en politiek hier samenkomen. Door het positioneren van de accountant als agent met twee principalen wordt een reeks van interessante onderzoeks- en beleidsvragen opgeworpen. Dit wordt versterkt door de transitie die het vakgebied momenteel doormaakt. De wetenschap kan mogelijk een bijdrage leveren om knelpunten in kaart te brengen en suggesties woor verbeteringen te doen. Ik hoop dat ik u vanmiddag heb kunnen overtuigen dat Auditing een fascinerend vakgebied is. 


\section{Dankwoord}

Gewardeerde toehoorders, nu ilk aan het einde van mijn oratie ben gekomen wil ik grag een woord van dank uitspreken. lk besef dat ik zonder de hulp en het vertrouwen van welen hier niet had gestaan. Op de eerste plaats dank aan het College wan Bestuur van de Universiteit Maastricht voor het in mij gestelde wertrouwen. Voorts will ik gaarne a! mijn leermeesters danken. Dat zijn er veel geweest en met het risico er velen te vergeten wil ik er een aantal in het bijzonder noemen. Op de eerste plaats mijn promotor Professor Willem Buijink. Vanaf mijn eerste dag als Alo in 1990 heb je me gecoacht en gestimuleerd in het doen van onderzoek. Het was een waar genoegen om onder jouw vieugels mijn eigen weg te vinden. De professoren Bram Beek, Jos en Tjeu Blommaert, Roger Dassen. Hans Kuifl, Steven Maijoor, Jan van de Poel en Arnold Schilder hebben als docent en collegai ieder een eigen rol gespeeld in minn vorming tot wetenschapper. Grote dank daarvoor. Voorts dank ik mijn collega's van het Departement AM. Eddy, Roger, Frank, Laury en alle anderen voor het creëren van een cultuur waarin kritisch denken wardt gestimuleerd. Ook dank aan curatoria, docenten en studenten van de postdoctorale opleidingen.

De aanwezigheid van mijn ouders, schoonouders, Kitty, Anke, Meike en Niek waardeer ik zeer. Ik stel voor jullie bij een andere gelegenheid mijn dankbaarheid te laten blijken woor het feit dat ik hier nu sta.

Ik heb gezegd. 


\section{Literatuuroverzicht}

Antle, $R .,(1982)$. The Auditor as an Economic Agent, Jaumal of Accounting Research, Vol.20, pp.503 527 .

Arens, A.A.y. J.K. Loebbecke, (2003), Auditing: An Integrated Approach. Prentice-Hall. Englewood Cliffs, N.

Bamberg, G. K. Spremann (eds.). (1989), Agency Theory Information, and incentives, Springer-Verlag, Berlijn.

Bindenga, A., (2002), Onafhankeligkheid in Financiële Zin. De Accountont, Oktober 2002, pp. 38-41.

Dassen, R.J.M. (1989), Leer van het Gewekte Ver trouwen: Agency avant-la-Lettre, Maandblad voar Accountanty en Bedriffseconomie, Vol.63. pp.341-352.

Fisher L., C. Quick, (2004). The Big Four old Boys' club, Accountancymagazine.com. Maart, p. 29.

Fleck, $\mathbb{R}$. , (2004), Taking an Ethical Lead, Accountancymagazine.com, Januari, p.127.

Flint, D. (1988), Philosophy and Principles of Auditing: An Introduction, MacMilan, Londen.

FNV, (1976), Open Boek: Een Nota over de Behoefte van Werknemers aan Informatie over hun Onderneming, Federatie Nederlandse Vakbeweging, Amsterdam.

Georgiou, $G_{.}$(2002). Copporate non-participation in the ASB standard-setting process, The European Accounting Review, 2002, Vol.11, pp.699-722.

Hassink, H.F.D., (2001), Use and Usefuness of Financial Accounting and Auditing: the case of trade unions bargainers, dissertatie, Universiteit Masstricht.

Hassink, H.F., (2003), Accountant moet Beloning Openbaar Maken, Het Financieele Dagblad, 31 december 2003.

Hen, de P.E., I.G. Berentsen, I.W. Schoonderbeek, (1995), Hoofdstukken uit de Geschiedenis wan het Nederlandse Accountantsberoep na 1935. Van Gorcum, Assen.

Kok, W. (1975a). De Maatschappelijke Behoefte aan Ondernemingsinformatie, in: Het Beroep onder de Loep, Verslag van Accountantsdag 1975. NIVRA geschrift no.15. pp.11-14 en pp.32-41, Nederlands Instituut van Registeraccountants, Amsterdam.

Kok, W., (1975,b), De Maatschappelijke Behoefte aan Ondernemingsinformatie, De Accountant, Vol. 49 , pp.422-4.24.

Limperg Instituut, (1987), Opvattingen over Accountants, Amsterdam.

Maljoor, 5.J. (1995). Dominees op de Markt: Een Economische Analyse van de Markt, het Kantoor en het Controleproces var Accountants, Oratie, Universiteit Malastricht.

Manson, S. M. Zaman, (1999), Lobbying the Auditing Practices, Board: Analysis of Responses to the Expanded Audit Report, Accounting Forum, Vol.23. pp.11-33. Moizer. P., (1991). Independence, in: Sherer, M. S. Tutley (eds.), Current issues in Auditing. Chapman Publishing, London.

NIVRA, (2003a). Richthinen woor de Accountantscontrole, Koninklijk Nederlands Instituut van Registeraccountants, Amsterdam.

NIVRA, (2003b), De Accountant \& Onafhankelijkheid: De Onafhankelikheidsregels en de Gevolgen voor de Dienstverlening van uw Accountant, Koninklijk Nederlands Instituut van Registeraccountants, Amsterdarn. 
Porter, B.A, (1993). An Empirical Study of the Audit Expectation Performance Gap. Accounting and Busines Research, Vol.24. p 49.68 .

Schilder, A. (1994a), Onathankelijkheid van Accountants: Fisse Blik en Vers Bloed. Gesprek met Johar Stekelenburg, De Accountant, Vol roo, pp.321-324.

Schilder, A.s (1994b), Onathankelikheid var Accountants: Maak het Deba Breder. cen Gesprek met A.A. Westeraken, De Accountant, Vol.100, pp,384-386.

Schilder, A, (7994C). Auditor Independence. An Exploratory study on Some Core Hs ues of Accountants "Ethics. Dissertation, Rijksuniwersiteit Groningen, Wolters Noordhoff, Groningen.

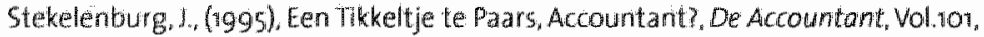
pp. $300-30 \%$.

Thorley Hill, N, SW, Shelton, KT. Stevens, (2002), Corporate Lobbying Behaviour on Accounting for Stark-based Compensation: Venue and Format Choices. Abocus, vol.38, pp.78-90.

Vries, De 1. (1985). Geschiedenis der Accountancy in Nederlands: Aanvang en Ontplooing: $895-1935$, Van Gorcum, Assen.

Watts, $R$, I. Zimmerman, (1986), Postive Accounting Theory, Prentice Hall, Englewood Cliffs, NI.

Watts, R, I. Zmmerman, (1990), Positive Accounting Theory: A Ten Year Perspective, The Accounting Review, Vol 65, ppisi-156.

Westerlaken, A.A. (1989). Werknemers en de Totstandkoming van Financiële Gegevens, De Accountant, Vol.95. pp.222"225. 